\title{
Manajemen Pembelajaran Bahasa Arab Menggunakan Google Classroom di SMK Muhammadiyah 01 Palembang
}

\author{
1* Hellen Tiara, 2Erni Wahyuningsih \\ 12UIN Sunan Kalijaga Yogyakarta \\ 1*hellentiara1001@gmail.com, 20.
}

الخلاصة: هذا البحث نوعي بطبيعته ، حيث درس الباحث في SMK Muhammadiyah 1 Palembang الطريقة الوصفية

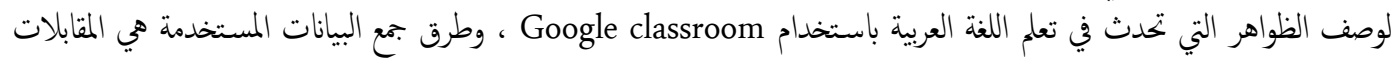

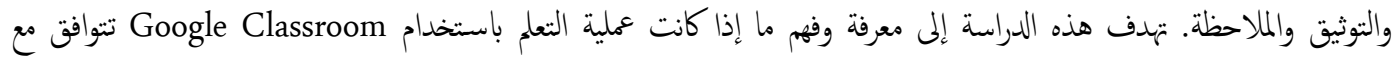
الأهداف المتوقعة في SMK Muhammadiyah 1 Palembang التي تركز على التخطيط لتعلم اللغة العربية وعملية تعلم اللغة

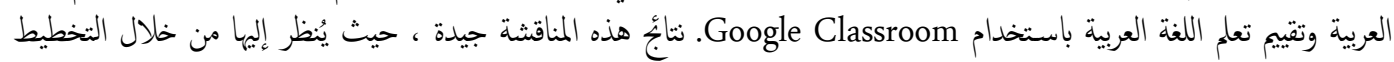

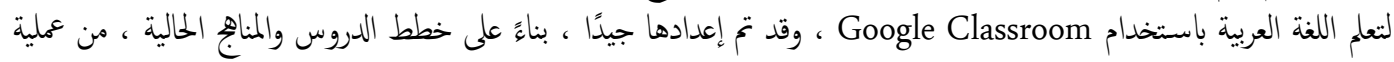

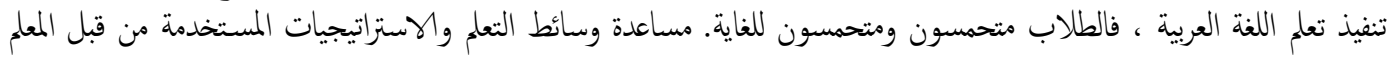

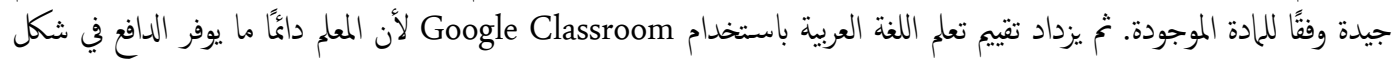

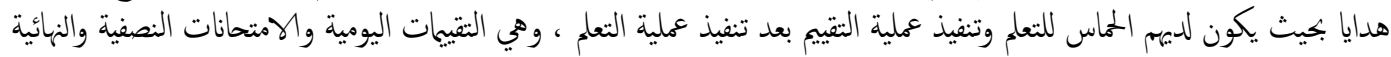

$$
\text { الكلمات المفتاحية: الإدارة ، تعلم اللغة العربية ، جوجل كلاس رووم ، التقييم }
$$

\begin{abstract}
This research is qualitative, where the researcher examines SMK Muhammadiyah 1 Palembang. The descriptive method is to describe the phenomena that occur in learning Arabic by using google classroom. This study aims to determine whether the learning process using Google Classroom follows the expected goals at SMK Muhammadiyah 1 Palembang, which focuses on planning Arabic learning, the Arabic learning process and evaluating Arabic learning using Google Classroom. The results of this discussion are good, seen from the planning of learning Arabic using Google Classroom, it has been well prepared, judging from the lesson plans and the existing syllabus, from the process of implementing Arabic learning, students are very enthusiastic and enthusiastic with the help of learning media and strategies used by the teacher is good per the existing material. Then the evaluation of Arabic learning using Google Classroom increases because the teacher always motivates in the form of gifts so that they have the enthusiasm to learn and carry out the assessment process after carrying out the learning process, namely daily assessments, midterm exams and final exams.
\end{abstract}

Keywords: Management, Arabic learning, Google Classroom, Evaluation

\section{PENDAHULUAN}

Perkembangan zaman sekarang ini tidak lepas dari teknologi informasi yang juga semakin berkembang. Teknologi informasi adalah salah satu dari banyak perangkat dalam mengantisipasi perubahan. Di era globalisasi teknologi informasi berperan 
sangat penting dalam menguasainya kita harus memiliki modal yang cukup untuk menjadi pemenang dalam persaingan global. Teknologi Informasi ini telah memungkinkan diwujudkannya pembelajaran yang efektif dan menyenangkan yang melibatkan siswa secara aktif. Kecanggihan teknologi mempengaruhi perubahan pembelajaran. Salah satu munculnya perkembangan teknologi dalam bidang pendidikan yaitu munculnya Google Classroom yang dirilis secara resmi pada tanggal 12 Agustus 2014, sesuai dengan namanya google mencoba memindahkan ruang kelas tersebut keranah Online.

Google Classroom merupakan sistem manajemen pembelajaran untuk sekolahsekolah dengan tujuan memudahkan pembuatan, pendistribusian dan penilaian tugas secara Paperless. Google Classroom berperan sebagai media atau alat yang dapat digunakan oleh pengajar dan siswa untuk menciptakan kelas online. Perkembangan Google Classroom juga bermanfaat untuk meingkatkan kualitas pendidikan, karena Google Classroom memfasilitator pembelajaran dengan kondisi siswa yang jaraknya jauh, siswa juga masih bisa menerima materi walaupun tidak ada didalam kelas.

Pembelajaran merupakan perpaduan dari dua aktivitas, yaitu: mengajar dan aktivitas belajar. Aktivitas belajar menyangkut peranan seorang guru dalam konteks mengupayakan terciptannya jalinan komunikasi harmonis antara pengajar dan pelajar. Jalinan komunikasi inilah yang menjadi indikator suatu aktivitas proses pembelajaran itu akan berjalan dengan baik. ${ }^{1}$ Suatu pembelajaran disebut berhasil, manakala ia mampu mengubah masalah-masalah yang ada pada peserta didik seperti dari suatu yang tidak tau, dari pemahaman yang keliru, dari terjebaknya dalam suatu mindset pemikiran yang salah. Menjadi suatu pengetahuan yang baru, pemahaman yang benar dan mindset yang terbuka.

Dalam suatu pembelajaran juga tidak terpisahkan dengan pengelolaan. Pengelolaan merupakan salah satu penopang kesuksesan dalam pembelajaran, pembalajaran tidak akan tercapai bila tidak memiliki komponen seperti, tujuan pemebelajaran, materi pembelajaran, metode pembelajaran, media pembelajaran, dan evaluasi pembelajaran, kesemua ini adalah syarat mutlak dalam mengelola pembelajaran. $^{2}$

Oleh sebab itu tugas dan tanggung jawab dalam pengelolaan berada di pundak seorang guru atau pengajar. Mengelola pembelajaran dengan lebih efektif, dinamis dan efesien serta positif, yang ditandai dengan adanya kesadaran dan keterlibatan aktif diantara dua subjek: guru sebagai penginisiatif awal serta pembimbing sedang peserta didik sebagai objek yang aktif terlibat dalam memperoleh perubahan diri dalam

\footnotetext{
${ }^{1}$ Ahmad Rohani, Pengelolaan Pembelajaran (Jakarta: Rineka Cipta, 2010), 1.

2 Rohani, Ahmad Rohani, Pengelolaan Pembelajaran......... 5.
} 
pembelajaran. ${ }^{3}$ Dengan bahasa lainnya guru dapat membawa siswanya pada suatu taraf pendewasaan atau taraf kematanagan tertentu, sehingga dalam rangka ini guru tidak semata-mata melakukan trenfer of knowledge, akan tetapi sebagai seorang pengajar juga melakukan transfer of value dan sekaligus sebagai pembimbing yang memberikan pengarahan dan menuntun siswa dalam belajar. ${ }^{4}$

Seperti pada pembelajaran bahasa pada umumnya, pembelajaran bahasa Arab memiliki problematika didalamnya, dimana problematika itu haruslah menemukan solusinya. Bahasa Arab adalah sebuah sistem, yaitu terdiri dari berbagai unsur dan komponen yang saling terkait dan saling mempengaruhi. Yang dimaksud dengan sistem adalah totalitas dari semua unsur yang saling terkait. ${ }^{5}$ Kualitas sistem sangatlah dipengaruhi oleh kualitas unsur-unsurnya, dan bila salah satu unsurnya tidak berjalan sesuai dengan unsur yang lain maka efektifitas akan terganggu. ${ }^{6}$ Maka Bahasa Arab itu sendiri ialah sebagai sistem yang terdiri dari berbagai aspek kebahasaan seperti gramatika, percakapan, membaca, menulis, dan menterjemahkan.

Oleh sebab itu perlunya sebuah formula untuk membuat pembelajaran Bahasa Arab dapat berjalan dengan singkat mudah dipahami dan memiliki daya nalar yang tanggap terhadap suatu kalimat serta cara penyusunan kalimat sesuai kaidah, maka semua ini perlu pengelolaan pembelajaran yang baik berdasarkan teorinya. Pengelolaan pembelajaran yang baik adalah mengacu pada suatu upaya untuk mengatur (mengelola, mengendalikan) aktivitas pembelajaran berdasarkan konsep-konsep dan prinsip pembelajaran untuk menyukseskan tujuan pembelajaran lebih efektif, efisien, dan produktif yang diawali dengan perencanaan, pelaksanaan dan diakhiri dengan penilaian. ${ }^{7}$

Berangkat dari teori yang telah dikemukakan diatas pengelolaan pembelajaran yang terjadi di tengah-tengah dunia pendidikan khususnya pembelajaran Bahasa Arab, sangat tidak sejalan dengan teori pengelolaan pembelajran yang sebagaimana yang ada dalam teori.begitu banyak fenomena yang seakan-akan tidak sesuai dengan teori tentang pengelolaan pembelajaran. Adapun fenomena yang terjadi banyak siswa yang menganggap pembelajaran Bahasa Arab sangat lah berat, seperti yang dikatakan oleh Arif Rahman Hakim dalam Jurnal Kebahasaannya para siswa begitu sulit untuk mempelajari kitab-kitab yang berbahasa Arab, seperti Jamiuddurus, Alfiyah, Imriti, dan

\footnotetext{
3 Rohani, Ahmad Rohani, Pengelolaan Pembelajaran ..............5.

${ }^{4}$ Sardiman A.M, Interaksi Dan Motivasi Belajar Mengajar (Jakarta: PT. Raja Grafindo, 2005),125.

${ }^{5}$ Munir, Perencanaan Sistem Pembelajaran Bahasa Arab Teori Dan Praktek Cet. II (yogyakarta: Idea Press, 2011), 5.

${ }^{6}$ Oemar Hamalik, Perencanaan Pengajaran Berdasarkan Pendekatan Sistem (Jakarta: Bumi Aksara, 2002), 1.

${ }^{7}$ Rohani, Ahmad Rohani, Pengelolaan Pembelajaran. 2.
} 
lain sebagainya, karena didalamnya siswa kesulitan memahami aturan-aturan dan prinsip-prinsip. ${ }^{8}$

Begitupun pembelajaran yang terjadi saat di SMK Muhammadiyah maupun SMA sekalipun, masih terjadi sistem pembelajaran yang terlalu berat, baik memberatkan siswa dan guru, praktek pengelolaan pembelajaran Bahasa Arab yang dibuat oleh guru yang masih sangat mengorbankan para siswa yang secara aktif harus membaca kitabkitab Bahasa Arab yang gundul mereka membaca secara terus menerus supaya lancar tanpa memahami maksud isi di dalam kitab, kemudian menghapal kaidah yang layaknya seperti syair lagu yang berbait-bait panjangnya namun pada kenyataannya proses ini lebih menekankan pada poin hapalnya saja, tanpa penjelasan secara mendasar dari arti gramtika yang dibahas. Dan sesuai dengan suatu permasalahan yang pernah diangkat oleh salah satu wisudawan yang meneliti bahwa adanya problematika didalam pengelolaan pembelajaran Skripsi saudari Miss Sareena Pohchaeh yang berjudul: "Problematika Pembelajaran Bahasa Arab Kelas VIII Madrasah Darasat Witya Narathiwat Thailand, Jurusan Bahasa Arab Fakultas Tarbiyah UIN Sunan Kalijaga Yogyakarta 2013." Dalam skripsi ini menjelaskan bahwa diantara problem-problem yang terjadi dalam pembelajaran bahasa Arab ialah karena Perencanaan, Pengorganisasian, Evalusi yang belum berjalan dengan baik. Sehingga masih jauhlah untuk mencapai pembelajaran bahasa Arab yang sesuai dengan tujuan. Dengan penelitian beliau ini menunjukkan bahwa pengelolaan pembelajaran yang terdiri dari komponen perencanaan, pelakasaan dan evaluasi memiliki peran yang sangat penting untuk mencegah problem yang bisa terjadi dalam pembelajaran bahasa arab.

Tentu hal diatas merupakan bagian fenomena pengelolaan yang masih menyimpang dari pengelolaan pembelajaran yang baik, karena yang demikian dalam prakteknya sangatlah menjenuhkan. Menurut peneliti Setelah semua hal yang membosankan tibalah saat yang menegangkan juga bagi siswa harus berhadapan dengan hukuman yang menjadi ciri khas apabila salah seorang siswa tidak mampu menghapal kaidah tersebut. Menurut peneliti semua hal tadi telah memberikan kesan yang buruk pada pembelajaran yang karna siswa hanya disuap tanpa terlaksanaya pembelajaran mandiri dan berkreasi.

Dari semua fenomena yang telah terjadi maka sepatutnyalah pengelolaan pembelajaran harus diatur sebaik mungkin, karna pengelolaan merupakan tonggak yang menopang pembelajaran. Adapun pengelolaan pembelajaran bahasa Arab dapat dilakukan dengan beberapa cara di antaranya: pertama, harus membatasi tujuan operasional yang sifatnya umum di setiap materi pembelajaran. Kedua, setiap tema

${ }^{8}$ Arif Rahman Hakim, 'Jurnal Al-Maqoyis, Vol. 1 No. 1, Jan-Juli 2013 Mempermudah Pembelajaran Ilmu Nahwu Pada Abad 20 Oleh: Arif Rahman Hakim', 1.1 (2013). 
dibatasi dengan tujuan pembelajaran. Ketiga, kesuksesan proses pembelajaran bahasa dalam memilih isi materi, soal, media, dan metode pembelajaran. Keempat. Penjelasan dalam tujuan operasional pembelajaran dapat memotivasi guru dan siswa untuk mencapai tujuan pembelajaran bahasa tersebut. ${ }^{9}$

Jika kita memadukan dengan pembelajaran bahasa Arab maka konteks pengelolaan yang baik adalah, proses pembelajaran bahasa Arab yang baik pada saat ini adalah pembelajaran yang memiliki inovasi dan kreasi dari seorang guru. Guru tidak boleh selalu ikut dalam suatu tradisi pembelajaran yang kuno karna sudah tidak sesuai dengan tuntutan zaman, era saat ini dimana siswa sangat memerlukan pembelajaran yang dinamis, sistemis dan tidak perlu berulang-ulang membaca juga tidak memerlukan bnyak waktu untuk memahami satu judul pembahasan. Pengelolaan pembalajaran bahasa Arab yang baik itu pula dimana guru menghindari dari proses membaca kitab terlalu lama hanya karena ingin melatih kemampuan membacanya padahal bisa dilakukan pada mata pelajaran yang sesuai dengan maharahnya.

Guru sebagai pengelola pembelajaran sebaiknya mampu menciptakan suasana yang baru dan menyenangkan. Menurut Thomas M Risk. Ciri seseorang guru memiliki pengelolaan yang baik jika dia dapat memberikan pengalamannya dalam pembelajaran merupakan hal yang baik (Teaching is the guidence of learning experience). Sama halnya dengan pembelajaran Bahasa Arab, pengalaman guru pernah belajar bahasa Arab adalah cara yang cerdas untuk dituangkan kepada siswa yaitu pemahaman yang sudah disimpulkan dan yang sudah diperbaiki yaitu suatu pemahaman yang mendalam oleh guru selama dia belajar himgga dia mengajar. Inilah yang membuat peneliti ingin menggali lebih dalam mengenai pengelolaan pembelajaran bahasa Arab dengan menggunakan google classroom yang baik di SMK muhammadiyah 1 Palembang.

\section{METODE PENELITIAN}

Penelitian ini merupakan penelitian kepustakaan (library research) dan pendekatan deskriptif kualitatif. Penelitian kepustakaan merupakan suatu penelitian atas kumpulan literatur ilmiah, buku, dokumen dan berbagai laporan yang berkaitan dengan masalah yang ingin dipecahkan.

\section{PEMBAHASAN}

\section{A. Pengelolaan Pembelajaran}

Goerge R Terry menyebutkan manajemen adalah suatu proses yang khas terdiri dari tindakan-tindakan perencanaan, pengorganisasian, penggerakan, dan pengendalian yang dilakukan untuk menentukan serta mencapai sasaran yang telah

${ }^{9}$ Mahmud Ahmad Sayyid, Fi Thara'iq Tadris Al-Lugha Al-Arabiyyah (Damaskus, 1997), 737. 
ditentukan melalui pemanfaatan sumber daya manusia dan sumber-sumber lainnya. ${ }^{10}$

Pengertian manajemen senada dengan pengertian pengelolaan. Pengelolaan adalah penyelenggaraan atau pengurusan agar sesuatu yang dikelola dapat berjalan dengan lancar, efektif, dan efisien. ${ }^{11}$ Dan pengelolaan dalam pengertian umum memiliki kesamaan arti yaitu pengadministrasian, pengaturan, atau penataan suatu kegiatan. ${ }^{12}$ Pengertian pengelolaan pembelajaran adalah mengacu pada suatu upaya untuk mengatur (memanage, mengendalikan) aktivitas pembelajaran berdasarkan konsep-konsep dan prinsip-prinsip pembelajaran bertujuan untuk tercapainya pembelajaran secara lebih efektif, efisien, dan produktif yang diawali dengan perencanaan dan diakhiri dengan penilaian. ${ }^{13}$

Husaini usman juga mendefinisikan tentang pengelolaan pembelajaran sebagai seni dan ilmu mengelola sumber daya pendidikan untuk mewujudkan suasana belajar dan proses pembelajaran agar peserta didik secara aktif mengembangkan potensi dirinya untuk memiliki kekuatan dalam belajar. Secara singkat dapat diartikan sebagai seni dan mengelola sumber daya pendidikan guna mencapai tujuan pendidikan secara efektif dan efisien. ${ }^{14}$

\section{B. Prinsip Pengelolaan}

Dalam kegiatan belajar mengajar, interaksi antara guru dan anak didik merupakan kegiatan yang dominan. Dalam kegiatan itu, guru tidak hanya mentransfer ilmu pengatahuan, tetapi juga mentransfer nilai-nilai kepada anak didik sebagai subyek yang belajar. Meskipun guru berperan sebagai medium, namun guru tidak akan dapat melaksanakan peranannya bila guru tidak menguasai bahan pelajaran sebelum melaksanakan tugas mengajar di muka kelas. Hal ini terutama untuk memudahkan guru melaksanakan perencanaan pembuatan (Satuan Pelajaran) sebagai awal dari seluruh pembelajaran. Materi pembelajaran/bahan pelajaran adalah hal-hal yang menjadi isi proses pembelajaran yang akan dikuasai oleh siswa. Pokok bahasan materi pelajaran tersebut tertuang dalam GBPP mata pelajaran.

Dapat dikatakan itu adalah suatu pembelajaran yang baik apabila pembelajaran memiliki pengelolaan pembelajaran yang kompleks. Adapun

10 Didin Kurniadi, Manajemen Pendidikan (Konsep Dan Prinsip Pengelolaan Pendidikan) (Yogyakarta: Ar-Ruzz Media, 2016), p. 26.

11 Suharsimi Arikunto, Menejemen Pengajaran Secara Manusiawi (Jakarta: Rineka Cipta, 1990), p.

8.

12 Arikunto, p. 8.

13 Rohani, p. 2.

${ }^{14}$ Husaini Usman, Manajemen Pendidikan (yogyakarta: PPs, 2004), p. 8. 
pendapat-pendapat yang lain akhirnya diambil kesimpulan bahwa kemampuan guru dalam mengelola proses belajar mengajar dikelompokkan menjadi 3 kelompok yaitu: 1) Kegiatan Merencanakan; 2) Kegiatan Melaksanakan; 3) Kegiatan Mengevaluasi.

Berikut penjelasan tiga prinsip-prinsip dari pengelolaan pembelajaran yang akan uraikan satu persatu dibawah ini:

1. Perencanaan pembelajaran

Menurut Wina Sanjaya perencanaan berasal dari kata rencana yaitu pengambilan keputusan tentang apa yang harus dilakukan umtuk mencapai tujuan. Dengan demikian proses suatu perencanaan harus lah dimulai dari penetapan tujuan yang akan dicapai melalui analisis kebutuhan serta dokumen yang lengkap, kemudian menetapkan langkah-langkah yang harus dilakukan untuk mencapai tujuan tersebut. Ketika kita merencanakan, maka pola pikir kita diarahkan bagaimana agar itu dapat dicapai secara efektif dan efisien.

Tujuan merupakan arah yang harus dicapai agar perencanaan dapat disusun dan ditentukan dengan baik, maka tujuan itu perlu dirumuskan dalam bentuk sasaran yang jelas dan terukur, dengan adanya sasaran yang jelas maka ada target yang harus dicapai. Target itulah yang selanjutnya mejadi fokus dalam menentukan langkah-langkah selanjutnya.

Perencanan pembelajaran juga sebagai proyeksi yang akan dilakukan pendidik untuk mencapai tujuan. ${ }^{15}$ Perencanaan adalah sebuah konseptualisasi dari sekian banyak aktivitas dalam bentuk program-program, tersusun secara sistematis, logis, jelas makna dan tujuannya. Perencanaan pembelajaran pada dasarnya merupakan bagian dari ilmu pendidikan dan pembelajaran yang tetntu tidak terpisahkan dengan ilmu-ilmu yang lainnya. Seperti ilmu psikologi pembelajaran, metode pembelajaran, administrasi pembelajaran, dan seterusnya. Mengingat luasnya cakupan perencanaan pembelajaran, maka perencanaan bersifat persiapan untuk mengajar di kelas dan biasanya dibuat berdasarkan kebutuhan pada setiap kali pertemuan. ${ }^{16}$

Membuat persiapan yang terencana sebelum mengajar merupakan salah satu langkah penting bagi kesuksesan pendidik dalam menngajar. Arti penting perencanaan bagi pendidik sebagai berikut: a) Dapat menjadi pedoman dalam mengajar, fokus materi, waktu yang dibutuhkan, metode yang akan diterapkan dan target yang dicapai; b) Lebih dapat memberikan rasa nyaman bagi peserta didik, karena proses akan terasa lebih sistematis; c) Dapat dimanfaatkan sebagai

15 Roger A Kaufman, Educational System Planing (New Jersey: Englewood Cliffs, 1972), 6.

${ }^{16}$ Abd al-Alim Ibrahim, Al-Wajih Al-Fanny (Kairo: Dar al-Ma'arif, 1973), 38. 
alat kontrol bagi lembaga terhadap proses pembelajaran yang berlangsung, termasuk dalam hal pencapaian target kurikulum.

Tahap perencanaan adalah tahap awal yang harus dilalui guru pada setiap proses belajar mengajar (PBM). Pada tahap ini guru mempersiapkan segala sesuatunya agar PBM yang akan dilaksanakan guru dapat berjalan secara efektif dan efisien. Dan anak didik ikut aktif dalam aktivitas belajar, proses belajar mengajar dikatakan efektif bila proses belajar mengajar yang menggunakan bahan pelajaran sesuai dengan waktu yang tersedia. Sedangkan yang dimaksud proses belajar mengajar yang efisien adalah proses belajar mengajar yang menggunakan semua bahan pelajaran dapat dipahami anak didik dan dikuasai.

Dalam merencanakan program pengajaran, langkah pertama yang dilakukan guru adalah merumuskan tujuan instruksional/tujuan pembelajaran. Tujuan instruksional inilah nantinya yang akan dijadikan pedoman guru dalam proses belajar mengajar. Tujuan instruksional memang salah satu sisi kegiatan yang harus dilakukan guru dalam tahap perencanaan aktivitas proses belajar mengajar. Unsur-unsur lainnya masih ada, yang kesemuanya harus ada dalam satuan pelajaran. Hal ini telah dirumuskan oleh Dr. Nana Sudjana dan Drs. Noeng Arifin sebagai berikut:

1. Merumuskan tujuan pembelajaran;

2. Menetapkan bahan pelajaran;

3. Kegiatan belajar siswa;

4. Metode mengajar dan alat bantu;

5. Pemilihan materi

2. Pelaksanaan pembelajaran

Pelaksanaan merupakan salah satu fungsi pengelolaan yang berfungsi untuk merealisasikan hasil dari perencanaan. Pelaksanaan adalah upaya untuk menggerakakkan atau mengarahkan tenaga kerja serta mendayagunakan fasilitas yang ada yang dimaksud untuk melaksanakn pekerjaan secara bersama. Pelaksaan bisa diartikan sebagai keseluruhan proses pemberian motif bekerja secara sungguh demi tercapainya tujuan. Fungsi pelaksanaan menempati posisi yang terpenting dalam merealisasikan segenap tujuan pembelajaran.

Dalam tahap pelaksanaan, guru melaksanakan aktivitas interaksi belajar mengajar dengan berpedoman pada persiapan pengajaran yang telah dibuat. Pemberian bahan pelajaran disesuaikan dengan urutan yang telah diprogramkan secara sistematis dalam tahap persiapan. Pada proses interaksi belajar mengajar, meski persiapan mengajar telah dipersiapkan sebagai langkah awal, namun guru tetap memperhatikan prinsip-prinsip mengajar, yakni: a) Perhatian; b) Aktivitas; 

c) Apersepsi;
d) Peragaan;
e) Ulangan;
f) Korelasi;
g) Konsentrasi; h) Individualisme; i) Sosialisasi. ${ }^{17}$

3. Evaluasi Pembelajaran

Prinsip-prinsip mengajar di atas adalah sebagai pedoman umum bagi guru dalam melaksanakan pengajaran. Dengan memperhatikan prinsip-prinsip mengajar itu guru akan mudah melaksanakan tugas mengajar di depan kelas.

Dalam pelaksanaan program interaksi belajar mengajar, guru terlebih dahulu harus mengadakan pretest untuk mengetahui penguasaan anak didik terhadap bahan pelajaran yang akan diberikan. Setelah itu guru memberikan bahan pelajaran, kemudian pada bagian akhir pelajaran guru mengadakan post test sebagai akhir dari seluruh proses interaksi belajar mengajar. Yang menjadi poin proses evaluasi yang dimaksud dalam pengelolaan ini adalah penilaian pada proses pengajaran.

Penilaian terhadap proses pengajaran dilakukan oleh guru sebagai bagian integral dari pengajaran itu sendiri. Artinya, penilaian harus tidak terpisahkan dalam penyusunan dan pelaksanaan pengajaran. Penilaian proses bertujuan menilai efektifitas dan efesiensi kegunaan pengajaran sebagai bahan untuk perbaikan dan penyempurnaan, program dan pelaksanaannya. Objek dan sasaran penilaian proses adalah komponen-komponen sistem pengajaran itu sendiri, baik yang berkenaan dengan masukan proses maupun dengan keluaran, dengan semua dimensinya.

\section{Pengertian Google Classroom}

Bahasa Arab memiliki empat kemahiran meliputi kemahiran menyimak, kemahiran berbicara, kemahiran membaca dan kemahiran menulis. ${ }^{18}$ Untuk mempelajari keempat kemahiran tersebut tentunya kita sebagai pendidik memiliki sebuah media penunjang dalam pembelaajran tersebut. Kali ini peneliti menawarkan google clasroom. Google Classroom merupakan sebuah aplikasi yang memungkinkan terciptanya ruang kelas di dunia maya. Aplikasi ini dapat memudahkan guru dan siswa dalam melaksanakan proses belajar dengan lebih mudah. Hal ini di sebabkan karena baik siswa maupun guru dapat mengumpulkan tugas, mendistribusikan tugas ,menilai tugas dirumah atau dimanapun tanpa terikat batas waktu atau jam pelajaran.

${ }^{17}$ Rohani, Ahmad Rohani, Pengelolaan Pembelajarn.............5-7.

${ }_{18}$ Hamalatul Quran and I I Sleman, Jurnal Pendidikan Bahasa Arab, Volume 3, Nomor 2,Desember 2020107 , 3, 107-32. 
Google classroom sesungguhnya dirancang untuk mempermudah intraksi guru dan siswa karena siapa saja bisa menggunakan aplikasi google classroom tergabung dengan kelas nya masing-masing. Aplikasi ini memberikan kesempatan kepada guru untuk mengeksplorasi gagasan keilmuan yang dimilikinya. Guru memiliki keleluasaan waktu untuk memberikan kajian keilmuan dan memberikan tugas mandiri kepada siswa selain itu, guru dapat membuka ruang diskusi secara Online. Namun demikian terdapat syarat mutlak dalam mengaplikasian google classrooom yaitu membutuhkan akses internet yang mumpuni.

Langkah-langkh pengaplikasian Google Classroom. Mengaplikasikan google classroom tentunya bukan hal mudah bagi guru yang tidak memiliki kemampuan dibidang teknologi informasi. Namun mi sungguh mengaplikasikan google classroom ini dapat dipelajari dengan memperhatikan langkah-langkah berikut ini.

a) Buka website google kemudian masuk dengan laman google classroom.

b) Pastikan anda memiliki akun google app for education. kunjungi classroom.google.com dan masuk. Pilih apakah anda seorang guru atau siswa, lalu buat kelas atau gabung kelas;

c) Jika anda administrator google apps, anda dapat menemukan informasi lebih lanjut tentang cara mengaktifkan dan menonaktifkan layanan di akses ke kelas;

d) Guru dapat menambahkan siswa secara langsung atau berbagi kode dengan kelasnya untuk bergabung. Hal ini berarti sebelumnya guru didalam kelas sudah memberi tahu siswa bahwa guru akan menerapkan google classroom dengan syarat siswa harus memiliki email pribadi dengan menggunakan nama lengkap pemiliknya;

e) Guru memberikan tugas mandiri atau melemparkan forum diskusi melalui laman tugas atau laman diskusi kemudian smeua materi kelas disimpan secara otomatis kedalam folder di google drive;

f) Selain memberikan tugas, guru jga dapat memebrikan pengumuman dan informasi terkait mata pelajaran yang kan dipelajari oleh siswa dikelas nyata pada laman tersebut;

g) Siswa dapat melacak setiap tugas yang hampir mendekati batas waktu pengumpulan dilaman tugas dan mulai mengerjakan cukup dengans sekali titik;

h) Guru dapat melihat dengan cepat siapa saja yang belum menyelesaikan tugas, serta memberikan masukan dan nilai langsung dikelas. 


\section{KESIMPULAN}

Berdasarkan pembahasan di atas, maka dapat disimpulkan bahwa salah satu persoalan yang sering ditemukan dalam proses pengajaran bahasa asing khususnya bahasa Arab adalah pemilihan metode pengajaran. Metode merupakan cara yang dilalui untuk menyampaikan materi pelajaran kepada peserta didik, sehingga tujuan pendidikan dapat tercapai. Kemudian dari pemaparan diatas menjelaskan pentingnya sebuah manajemen/pengelolaan dalam melakukan proses pembelajaran. Adapun media yang dapat menjadi alternatif pada pembelajaran bahasa Arab ialah google clasroom.

\section{DAFTAR PUSTAKA}

A.M, Sardiman, Interaksi Dan Motivasi Belajar Mengajar (Jakarta: PT. Raja Grafindo, 2005)

Arikunto, Suharsimi, Menejemen Pengajaran Secara Manusiawi (Jakarta: Rineka Cipta, 1990)

Hakim, Arif Rahman, 'Jurnal Al-Maqoyis, Vol. 1 No. 1, Jan-Juli 2013 Mempermudah Pembelajaran Ilmu Nahwu Pada Abad 20 Oleh: Arif Rahman Hakim', 1.1 (2013)

Hamalik, Oemar, Perencanaan Pengajaran Berdasarkan Pendekatan Sistem (Jakarta: Bumi Aksara, 2002)

Ibrahim, Abd al-Alim, Al-Wajih Al-Fanny (Kairo: Dar al-Ma'arif, 1973)

Kaufman, Roger A, Educational System Planing (New Jersey: Englewood Cliffs, 1972)

Kurniadi, Didin, Manajemen Pendidikan (Konsep Dan Prinsip Pengelolaan Pendidikan) (Yogyakarta: Ar-Ruzz Media, 2016)

Munir, Perencanaan Sistem Pembelajaran Bahasa Arab Teori Dan Praktek Cet. II (yogyakarta: Idea Press, 2011)

Quran, Hamalatul, and I I Sleman, 'Jurnal Pendidikan Bahasa Arab, Volume 3, Nomor 2,Desember 2020 107', 3, 107-32

Rohani, Ahmad, Pengelolaan Pembelajaran (Jakarta: Rineka Cipta, 2010)

Sayyid, Mahmud Ahmad, Fi Thara'iq Tadris Al-Lugha Al-Arabiyyah (Damaskus, 1997)

Usman, Husaini, Manajemen Pendidikan (yogyakarta: PPs, 2004) 